Bull. Fac .Agric., Cairo Univ., 65: 170- 182 (2014).

\title{
RESPONSE OF TWO CULTIVARS OF Ficus alii L. TO FOLIAR APPLICATION OF SOME TRACE ELEMENT TREATMENTS
}

(Received : 21.3. 2014)

\author{
By \\ A. B. El- Attar \\ Ornamental Horticulture Department, Faculty of Agriculture, Cairo University, Giza, Egypt
}

\begin{abstract}
This study was carried out in the glasshouse of the nursery of Ornamental Horticulture Department, Faculty of Agriculture, Cairo University, Giza, during the two successive years 2012 and 2013. The aim was to investigate the response of two cultivars of Ficus alii, cv. "Green" and "Variegata" to some treatments of foliar application of trace elements. The seedlings were sprayed with $\mathrm{Zn}, \mathrm{Fe}$ and $\mathrm{Mn}$ at the rate of $50 \mathrm{mg} / \mathrm{l} / 3$ weeks, and Borax at the rate $10 \mathrm{mg} / \mathrm{l} / 3$ weeks, while the control plants were sprayed with tap water. All the plants were monthly fertilized with life green (NPK, 20-20-20) at the rate of $2 \mathrm{~g} /$ pot.

Foliar application treatments of $\mathrm{Zn}, \mathrm{Fe}, \mathrm{Mn}$ and $\mathrm{B}$ significantly increased all the vegetative growth parameters as well as the contents of total chlorophylls $(\mathrm{a}+\mathrm{b})$, total carbohydrates treatment, N, P , K, $\mathrm{Zn}, \mathrm{Fe}, \mathrm{Mn}$ and B ppm treatment in the leaves as compared with the control plants. On the other hand, trace elements treatment (in most cases) caused significant decrease in carotenoids content in the leaves compared to the untreated ones.

In both seasons, Ficus alii cv. "Green" had plant height, leaf area as well as carotenoids content in leaves which were significantly higher than those of cv. "Variegata". On the other hand, the cv. "Variegata" had the number of leaves, stem diameter, fresh and dry weights of shoots and roots as well as contents of total chlorophylls, total carbohydrates percentage, N, Zn, Fe Mn and B contents which were significantly higher than those of cv. "Green".

From the above results, it can be recommended that for the best vegetative growth of Ficus alii cvs. "Green" and "Variegata", the plants sprayed with Fe, Zn or Mn at $50 \mathrm{mg} / \mathrm{l} / 3$ weeks and/or B at 10 $\mathrm{mg} / \mathrm{l} / 3$ weeks and fertilized by $2 \mathrm{~g} /$ pots/ month of chemical fertilizer (NPK, 20-20-20), should be foliar sprayed
\end{abstract}

Key words: Cultivars, Ficus alii, Micronutrients (zinc, iron, manganese, boron).

\section{INTRODUCTION}

Ficus alii ( $F$. binnendijkii "alii" or, $F$. maclellandii "alii", Family: Moraceae) is an interesting foliage plant, native to Philippines, Thailand and Costa Rica. It is a tree of dense growth and pendant habit which may grow to several meters in height. Its relatively thick leaves are lance-shaped (willow-like leaves), shiny, deep green up to $10^{\prime \prime}$ long and tapering to a slender point and leaf width depends on variety. New growth is sometimes tinted bronze and later matures to a deep, rich green. Ficus alii tolerates a wide range of light, temperature, and watering conditions without losing its leaves. It lacks the tendency to shed leaves.

In the commercial production of ornamental plants, the applications of both macro nutrients
(NPK) and one or more of the trace elements (micro nutrients) are the most recommended fertilization regime. Trace elements such as zinc $(\mathrm{Zn})$, iron $(\mathrm{Fe})$, manganese $(\mathrm{Mn})$ and boron $(\mathrm{B})$ play a vital role in the various physiological and biochemical processes that occur within the plant and they are necessary for normal plant growth and development. However, the amount needed from these elements are so small (Allen and David, 2007). Functions and mode of action for trace elements were explained by (Marschner, 1995 and Taiz and Zeiger, 2002). Zinc ( $\mathrm{Zn})$ is an essential element for plant that acts as a metal component of various enzymes (almost 60 enzymes) or as a functional structural or regulatory cofactor for protein synthesis, photosynthesis, carbohydrate metabolism, the 
synthesis of auxin, cell division and maintains of membrane structure. Iron $(\mathrm{Fe})$ involved with chlorophyll synthesis, plays an essential role in plant metabolism and complexes with proteins to form important enzymes in the plant. Manganese (Mn) participates in several important processes including photosynthesis, and metabolism of both nitrogen and carbohydrate (Taiz and Zeiger, 2002). Boron (B) plays an important role in sugar translocation and carbohydrate metabolism, also is involved with cell division, differentiation, growth, and respiration. Foliar feeding is a relatively new and controversial technique of feeding plants by applying liquid fertilizer directly to their leaves (Taiz and Zeiger, 2002). Since the trace elements are needed for plants in small amounts, applying them as foliar spraying at the right time is a correct way to save the plant requirements (Kuepper, 2003). In this respect, the effects of foliar application of trace elements on growth of ornamental and foliage plants have been studied by several investigators who reported improved vegetative growth parameters (including plant height, the number of leaves/plant, leaf area, stem diameter, fresh and dry weights of shoots and roots). In addition increments in pigment contents and total carbohydrates have been also reported due to foliar spraying of trace elements on Dieffenbachia (Dorgham 2005), Philodendron and Syngonium (Mazhar et al., 2006), Taxodium disticum (Abd El-Aziz and Balbaa 2007), Salvia farinacea (Farahat et al. 2007), Cupressus sempervirens (Naguib et al. 2007), Codiaeum variegatum cv. "Gold Star", Ruta graveolens (Esmail 2008), Dracaena marginata (Heider 2010), Areca lutescens (El-Attar 2011). Treatments of $\mathrm{Ca}, \mathrm{Mg}, \mathrm{Fe}$ and $\mathrm{Zn}$ significantly increased plant height, stem diameter, leaf area and the number of leaves. However, the available data of published research as regards the effect of trace elements on Ficus alii are very limited.

Therefore, this study aimed to investigate the response of two cultivars of Ficus alii cv. ("Green" and "Variegata") to foliar application of trace elements on growth and biochemical composition.

\section{MATERIALS AND METHODS}

This study was carried out in the glasshouse of the Nursery of Ornamental Horticulture Department, Faculty of Agriculture, Cairo University, Giza, Egypt, during the two successive years 2012 and 2013. The aim of this study was to investigate the effect of foliar application of different trace elements on the growth and chemical constituents of two cultivars of Ficus alii cv. "Green" and "Variegata".

On $1^{\text {st }}$ of March, 2012 and 2013 (in the first and second seasons, respectively), uniform seedlings from both cultivars of Ficus alii (with an average plant height of $15-18 \mathrm{~cm}$ ), were planted in 30-cm diameter plastic pots filled with the mixture of clay plus sand plus peat moss $(1: 1: 1 \mathrm{v} / \mathrm{v} / \mathrm{v})$. The physical and chemical characteristics of the mixed media are shown in Table (1).

Table (1):Physical and chemical characteristics of the soil media used for growing two cultivars of Ficus alii plants.

\begin{tabular}{|l|c|l|c|}
\hline Treatments & value & Treatments & value \\
\hline $\mathbf{p H}$ & 7.62 & Course sand & 4.3 \\
\hline $\mathbf{E . C ~ d s / m ~}$ & 0.8 & Fine Sand & 30.2 \\
\hline $\mathbf{H C O}_{\mathbf{3}}+\mathbf{C O}_{\mathbf{3}}$ & 1.8 & Silt & 39.2 \\
\hline $\mathbf{C l}^{-}$ & 1.6 & Clay & 26.3 \\
\hline $\mathbf{S O}_{\mathbf{-}}^{-}$ & 4.6 & Texture class & Loamy \\
\hline $\mathbf{C a}^{++}$ & 3.6 & & \\
\hline $\mathbf{M g}^{++}$ & 0.6 & & \\
\hline $\mathbf{N a}^{+}$ & 2.2 & & \\
\hline $\mathbf{K}^{+}$ & 1.6 & & \\
\hline
\end{tabular}

From $21^{\text {st }}$ of March till $31^{\text {st }}$ of October (in both years), the plants were sprayed every 3 weeks with the separated solutions of $\mathrm{Zn}, \mathrm{Fe}$ and Mn (EDTA-Chelated form 13\%, 6\% and 13\% respectively) at the rate of $50 \mathrm{mg} / 1$. Boron was also used as a foliar spray at the rate of $10 \mathrm{mg} / \mathrm{l}$ (borax 11.4\%). In addition, the control plants were sprayed with tap water. Bio-film was added at $1 \mathrm{ml} / 1$ to each solution as a wetting agent. Foliar application of each treatment was carried out after 21 days from transplanting, using a hand sprayer until run off point.

All plants received the soluble chemical fertilizer [life green (NPK, 20-20-20)], which was applied monthly at the rate of $2 \mathrm{~g} / \mathrm{pot}$, other common agricultural practices including regular watering, hand picking of weeds were also preformed.

The layout of the experiment was a complete randomized block design, with 3 blocks (replicates). The study included 10 treatments [5 trace elements treatments (including the control) x 2 cultivars of Ficus alii], with each block consisting of 50 plants (5 plants/treatment). 
On $21^{\text {st }}$ of November 2012 and 2013 (in both years, respectively), the experiment was terminated and the vegetative growth parameters were recorded, including plant height $(\mathrm{cm})$, the number of leaves/plant, leaf area $\left(\mathrm{cm}^{2}\right)$, stem diameter $\mathrm{cm}$, at $5 \mathrm{~cm}$. above soil surface, as well as fresh and dry weights of shoots and roots/plant (g/ plant). Also, chemical analysis of fresh leaf sample was conducted to determine their total chlorophylls $(\mathrm{a}+\mathrm{b})$ and carotenoids contents (mg/g Fresh weight) using the method recommended by Saric et al. (1967). In addition, the total carbohydrate content (\% of Dry weight) was determined in dried leaves using the colorimetric method as described by Dubois et al. (1956). Dried samples were digested to extract nutrients as described by Piper (1947), and the extract was chemically analyzed to determine its contents of nitrogen, phosphorus and potassium ( $\%$ of Dry weight). Nitrogen percentage was determined using the modified micro-Kjeldahl method as described by Pregl (1945), while phosphorus percentage was estimated using the method recommended by Troug and Meyer (1939). The potassium percentage was determined by using a Jenway flamephotometer, according to Chapman and Pratt, (1961). The contents of Fe, Mn, Zn and B (ppm) in the extract were also determined by using Flame Atomic Absorption JENWAY PFP7 with a boiling air-acetylene burner as recommended by (Isaac and Kerber, 1971). The data recorded on vegetative growth characteristics and chemical constituents were statistically analyzed. An analysis of variance (ANOVA) was carried out, and the means of the recorded data were compared using the "Least Significant Difference (L.S.D.)" test at the 5\% level, as described by Steel and Torrie (1980).

\section{RESULTS AND DISCUSSION}

\subsection{Vegetative growth characteristics}

The results recorded in the two years of the experiments (Tables 2 and 3) indicated that foliar application of the different trace elements treatments $(\mathrm{Fe}, \mathrm{Zn}, \mathrm{Mn}$ and $\mathrm{B})$ had a considerable effect on vegetative growth characteristics such as: plant height, the number of leaves/plant, leaf area, stem diameter, fresh and dry weights of shoots as well as fresh and dry weights of roots. Foliar spraying of trace elements promoted vegetative growth, and resulted in significant increases in the values recorded for the different growth parameters, compared to the untreated control plants. Similar promotion of vegetative growth as a result of trace elements has been reported by El-Fadaly (1994) on Jasminum sambac, Said (1997) on Codiaeum variegatum El- Deeb (1999) on Aspelinium nidus and Philodendron erubescens, Mansour (2002) on Scindapsus pictus, Dorgham (2005) on Dieffenbachia, Philodendron and Syngonium, Gomaa and Ragab (2005) on Codiaeum variegatum, Al-Hadad (2006) on Cupressus macrocarpa, Mazhar et al. (2006) on Taxodium disticum, Abd El-Aziz and Balbaa (2007) on Salvia farinacea, Farahat et al. (2007) on Cupressus sempervirens, Naguib et al. (2007) on Ruta graveolens, El-Bagoury et al. (2008) on Hedera helix, Esmail (2008) on Codiaeum variegatum cv. "Gold Star", Heider (2010) on Dracaena marginata, Kumar and Haripriya (2010) on Nerium odorum, Eid et al.(2010) on Polianthes tuberose, and El- Attar (2011) on Areca lutescens.

The favorable effect of the trace elements on the vegetative growth characteristics (compared to the control) can be explained by the important role of these elements in the different physiological and biochemical processes within the plant, which in turn affect the plant growth (Allen and David, 2007).

The data in both seasons (Tables 2and 3) clearly revealed also that, foliar application of Mn treatments appeared to be the most effective treatment for increasing plant height, the number of leaves/plant, leaf area, fresh and dry weights of shoots as well as fresh and dry weights of roots, compared to the other treatments. On the other hand, the most effective treatment for increasing stem diameter (in both seasons) was foliar spraying of B followed by the application of $\mathrm{Mn}$ treatments.

Concerning the cultivar of Ficus alii, regardless of the effect of foliar application of trace elements the data in Tables (2) and (3) showed that, in both seasons, the values recorded on plant height and leaf area of the cv. "Green" were significantly higher than those recorded on the same parameters of the cv. "Variegata" as compared to each other. On the other hand, in both seasons the cv. "Variegata" had the number of leaves, stem diameter, fresh and dry weights of shoots as well as fresh and dry weights of roots which were significantly higher than the same values recorded for the cv. "Green".

Regarding the interaction effect between foliar application of trace elements and Ficus alii 
Table (2): Effect of foliar application of trace elements on plant height, the number of leaves/plant, leaf area and stem diameter of Ficus alii cvs. "Green" and "Variegata", during the 2012 and 2013 seasons.

\begin{tabular}{|c|c|c|c|c|c|c|}
\hline \multirow{3}{*}{$\begin{array}{c}* \text { Trace elements } \\
\text { treatments }(\mathbf{T})\end{array}$} & \multicolumn{3}{|c|}{ First season (2012) } & \multicolumn{3}{|c|}{ Second season (2013) } \\
\hline & \multicolumn{2}{|c|}{ Cultivars (C) } & \multirow{2}{*}{$\begin{array}{l}\text { Mean } \\
(\mathrm{T})\end{array}$} & \multicolumn{2}{|c|}{ Cultivars( C) } & \multirow{2}{*}{$\begin{array}{c}\text { Mean } \\
(\mathbf{T})\end{array}$} \\
\hline & Green & Variegata & & Green & Variegata & \\
\hline \multicolumn{7}{|c|}{ Plant height $(\mathrm{cm})$} \\
\hline Control & 35.27 & $28 . \overline{13}$ & 31.70 & 38.32 & 30.16 & 34.24 \\
\hline $\mathbf{Z n}$ & 46.38 & 32.92 & 39.65 & 50.29 & 33.48 & 41.89 \\
\hline $\mathbf{F e}$ & 44.36 & 36.20 & 40.28 & 54.35 & 39.36 & 46.85 \\
\hline Mn & 48.31 & 37.10 & 42.71 & 58.36 & 38.14 & 48.25 \\
\hline B & 45.33 & 41.16 & 43.24 & 47.70 & 44.10 & 45.90 \\
\hline Mean (C) & 43.93 & 35.10 & ------- & 49.80 & 37.05 & ------- \\
\hline \multicolumn{7}{|l|}{ L.S.D. (0.05) } \\
\hline $\mathbf{T}$ & \multicolumn{3}{|c|}{0.66} & \multicolumn{3}{|c|}{0.42} \\
\hline $\mathbf{C}$ & \multicolumn{3}{|c|}{0.38} & \multicolumn{3}{|c|}{0.24} \\
\hline T X C & \multicolumn{3}{|c|}{0.94} & \multicolumn{3}{|c|}{0.60} \\
\hline \multicolumn{7}{|c|}{ Number of leaves/plant } \\
\hline Control & 21.08 & 17.01 & 19.05 & 27.50 & 20.73 & 24.11 \\
\hline Zn & 26.28 & 35.07 & 30.67 & 32.36 & 39.63 & 36.00 \\
\hline $\mathbf{F e}$ & 24.04 & 43.11 & 33.58 & 33.95 & 45.50 & 39.72 \\
\hline Mn & 31.54 & 51.10 & 41.32 & 36.27 & 53.45 & 44.86 \\
\hline $\mathbf{B}$ & 25.04 & 45.61 & 35.33 & 28.36 & 47.16 & 37.76 \\
\hline Mean (SL) & 25.60 & 38.38 & -------- & 31.69 & 41.29 & +------ \\
\hline \multicolumn{7}{|l|}{ L.S.D. (0.05) } \\
\hline $\mathbf{T}$ & \multicolumn{3}{|c|}{1.62} & \multicolumn{3}{|c|}{2.50} \\
\hline C & \multicolumn{3}{|c|}{0.94} & \multicolumn{3}{|c|}{1.44} \\
\hline T X C & \multicolumn{3}{|c|}{2.29} & & 3.54 & \\
\hline & & Leaf & $\mathbf{c m}^{2}$ & & & \\
\hline Control & 17.67 & 16.16 & 16.92 & 19.50 & 18.39 & 18.94 \\
\hline $\mathbf{Z n}$ & 23.92 & 21.06 & 22.49 & 25.60 & 22.73 & 24.16 \\
\hline $\mathbf{F e}$ & 23.55 & 19.80 & 21.67 & 26.51 & 21.90 & 24.20 \\
\hline Mn & 24.87 & 22.67 & 23.77 & 25.71 & 23.16 & 24.43 \\
\hline B & 21.66 & 23.68 & 22.67 & 24.60 & 20.86 & 22.73 \\
\hline Mean (SL) & 22.33 & 20.67 & ------ & 24.38 & 21.41 & ----- \\
\hline L.S.D. (0.05) & & & & & & \\
\hline $\mathbf{T}$ & & 0.52 & & & 0.40 & \\
\hline $\mathbf{C}$ & & $\mathbf{0 . 3 0}$ & & & 0.23 & \\
\hline TX C & & 0.73 & & & 0.54 & \\
\hline & & Stem dia & $\operatorname{ter}(\mathrm{mm}$ & & & \\
\hline Control & 0.38 & 0.42 & 0.40 & 0.40 & 0.45 & 0.43 \\
\hline $\mathbf{Z n}$ & 0.46 & 0.61 & 0.54 & 0.47 & 0.66 & 0.57 \\
\hline $\mathbf{F e}$ & 0.49 & 0.66 & 0.58 & 0.51 & 0.71 & 0.61 \\
\hline Mn & 0.53 & 0.72 & 0.63 & 0.55 & 0.79 & 0.67 \\
\hline B & 0.50 & 0.80 & 0.65 & 0.59 & 0.82 & 0.71 \\
\hline Mean (SL) & 0.47 & 0.64 & ----- & 0.50 & 0.69 & ---- \\
\hline L.S.D. (0.05) & & & & & & \\
\hline $\mathbf{T}$ & & 0.12 & & & 0.13 & \\
\hline $\mathbf{C}$ & & 0.09 & & & 0.09 & \\
\hline TX C & & 0.20 & & & 0.21 & \\
\hline
\end{tabular}

\footnotetext{
* Zn, Fe and Mn $=50 \mathrm{mg} / \mathrm{l} \quad \mathrm{B}=10 \mathrm{mg} / \mathrm{l}$
} 
Table (3): Effect of foliar application of trace elements on shoot and root fresh and dry weights (g/plant) of of Ficus alii cvs "Green" and "Variegata", during the 2012 and 2013 seasons.

\begin{tabular}{|c|c|c|c|c|c|c|}
\hline \multirow{3}{*}{$\begin{array}{r}* \text { Trace elements } \\
\text { treatments }(\mathbf{T})\end{array}$} & \multicolumn{3}{|c|}{ First season (2012) } & \multicolumn{3}{|c|}{ Second season (2013) } \\
\hline & \multicolumn{2}{|c|}{ Cultivars (C) } & \multirow{2}{*}{$\begin{array}{l}\text { Mean } \\
\text { (T) }\end{array}$} & \multicolumn{2}{|c|}{ Cultivars (C) } & \multirow{2}{*}{$\begin{array}{l}\text { Mean } \\
(\mathbf{T})\end{array}$} \\
\hline & Green & Variegata & & Green & Variegata & \\
\hline \multicolumn{7}{|c|}{ Fresh weight of shoots (g/plant) } \\
\hline Control & 6.97 & 17.01 & 11.99 & 8.84 & 20.73 & 14.78 \\
\hline $\mathbf{Z n}$ & 14.87 & 49.68 & 32.27 & 16.87 & 51.41 & 34.14 \\
\hline $\mathbf{F e}$ & 12.76 & 65.43 & 39.10 & 18.93 & 70.11 & 44.52 \\
\hline Mn & 16.93 & 80.36 & 48.65 & 23.53 & 88.04 & 55.78 \\
\hline $\mathbf{B}$ & 13.80 & 66.98 & 40.39 & 15.91 & 72.32 & 44.12 \\
\hline Mean (C) & 13.07 & 55.89 & ----- & 16.82 & 60.52 & ----- \\
\hline \multicolumn{7}{|l|}{ L.S.D. (0.05) } \\
\hline $\mathbf{T}$ & \multicolumn{3}{|c|}{1.33} & \multicolumn{3}{|c|}{1.69} \\
\hline $\mathrm{C}$ & \multicolumn{3}{|c|}{$\mathbf{0 . 7 7}$} & \multicolumn{3}{|c|}{0.97} \\
\hline TX C & \multicolumn{3}{|c|}{1.88} & \multicolumn{3}{|c|}{2.38} \\
\hline \multicolumn{7}{|c|}{ Dry weight of shoots(g/plant) } \\
\hline Control & 1.89 & 3.75 & 2.82 & 2.03 & 4.95 & 3.49 \\
\hline $\mathbf{Z n}$ & 3.71 & 12.87 & 8.29 & 4.87 & 13.11 & 8.99 \\
\hline $\mathbf{F e}$ & 3.19 & 14.09 & 8.64 & 5.90 & 16.10 & 11.00 \\
\hline Mn & 5.01 & 20.00 & 12.51 & 7.88 & 24.54 & 16.21 \\
\hline B & 3.55 & 14.81 & 9.18 & 4.98 & 17.23 & 11.11 \\
\hline Mean (SL) & 3.47 & 13.10 & $\begin{array}{ll}---- \\
\end{array}$ & 5.13 & 15.19 & $\begin{array}{ll}---- \\
\end{array}$ \\
\hline \multicolumn{7}{|l|}{ L.S.D. (0.05) } \\
\hline $\mathbf{T}$ & \multicolumn{3}{|c|}{0.46} & \multicolumn{3}{|c|}{0.25} \\
\hline C & \multicolumn{3}{|c|}{$\mathbf{0 . 2 7}$} & \multicolumn{3}{|c|}{0.14} \\
\hline T X C & \multicolumn{3}{|c|}{0.65} & & $\mathbf{0 . 3 5}$ & \\
\hline & & Fresh we & of roots $(\mathrm{g}$ & lant) & & \\
\hline Control & 2.52 & 4.93 & 3.73 & 1.88 & 10.38 & 6.13 \\
\hline $\mathbf{Z n}$ & 4.83 & 18.69 & 11.76 & 3.46 & 12.79 & 8.13 \\
\hline $\mathbf{F e}$ & 6.51 & 28.57 & 17.54 & 2.93 & 20.89 & 11.91 \\
\hline Mn & 9.83 & 49.04 & 29.44 & 9.53 & 24.36 & 16.94 \\
\hline B & 3.12 & 10.84 & 6.98 & 2.18 & 15.93 & 9.06 \\
\hline Mean (SL) & 5.36 & 22.41 & --------- & 4.00 & 16.87 & ------- \\
\hline L.S.D. (0.05) & & & & & & \\
\hline $\mathbf{T}$ & & 0.45 & & & 0.82 & \\
\hline $\mathrm{C}$ & & 0.26 & & & 0.47 & \\
\hline TX C & & $\mathbf{0 . 6 3}$ & & & 1.16 & \\
\hline & & Dry we & of $\operatorname{roots}(\mathrm{g} / \mathrm{s}$ & ant) & & \\
\hline Control & 0.86 & 1.00 & 0.93 & 0.68 & 2.74 & 1.71 \\
\hline $\mathbf{Z n}$ & 1.45 & 4.67 & 3.06 & 1.25 & 3.07 & 2.16 \\
\hline $\mathbf{F e}$ & 1.93 & 7.14 & 4.54 & 1.06 & 4.61 & 2.84 \\
\hline Mn & 3.19 & 12.26 & 7.73 & 3.00 & 5.01 & 4.01 \\
\hline B & 0.91 & 2.50 & 1.71 & 0.80 & 3.57 & 2.19 \\
\hline Mean (SL) & 1.67 & 5.51 & ----- & 1.36 & 3.80 & ----- \\
\hline L.S.D. (0.05) & & & & & & \\
\hline $\mathbf{T}$ & & 0.23 & & & 0.43 & \\
\hline $\mathrm{C}$ & & 0.13 & & & 0.25 & \\
\hline TXC & & 0.32 & & & 0.61 & \\
\hline
\end{tabular}

* $\mathrm{Zn}, \mathrm{Fe}$ and $\mathrm{Mn}=50 \mathrm{mg} / \mathrm{l} \quad \mathrm{B}=10 \mathrm{mg} / \mathrm{l}$ 
cultivars, the data recorded on the vegetative growth (Table 2) showed that in both seasons within both cultivars of Ficus alii, foliar application of the different trace elements treatments caused a significant increase in plant height, the number of leaves/plant, leaf area, fresh and dry weights of shoots as well as fresh and dry weights of roots as compared to the control plants. In both seasons, the cv. "Green" foliar sprayed with any of the trace element treatments had stem diameter insignificantly higher than those of the control plants, while application of these different treatments, in most cases, significantly increased stem diameter of the cv. "Variegata". In both seasons, the highest values recorded for most of the growth parameters of both studied cultivars were obtained from plants received $\mathrm{Mn}$ treatment, while the highest values of plant height, leaf area and stem diameter (in cv. "Green") resulted from plants sprayed with $\mathrm{Mn}$ treatment.

\subsection{Chemical constituents}

\subsubsection{Total chlorophylls $(a+b)$ and carotenoids $\mathrm{mg} / \mathrm{g} \mathrm{F} / \mathrm{W}$}

Data presented in Table (4) indicated that foliar application of trace elements was very beneficial in terms of the total chlorophylls content in leaves of Ficus alii plants. In both seasons, spraying the plants with any solution of the tested trace elements significantly increased total chlorophyll content in the leaves, compared to the control. Increases in chlorophyll content as a result of the different trace element treatments were similar with the findings of ElFadaly (1994) on Jasminum sambac, Said (1997) on Codiaeum variegatum, El - Deeb ( 1999 ) on Aspelinium nidus and Philodendron erubescens, Mansour (2002) on Hedra helix, Mazhar et al. (2006) on Taxodium disticum, Abd El-Aziz and Balbaa (2007) on on Salvia farinacea, Farahat et al. (2007) on Cupressus sempervirerns and Esmail (2008) on Codiaeum variegatum cv. "Gold Star". Kumar and Haripriya (2010) on Nerium odorum.

In the case of the carotenoides $\mathrm{mg} / \mathrm{g} \mathrm{FW}$ content, the data recorded in both seasons revealed that, in most cases, application of any trace elements significantly decreased carotenoide content in the leaves compared to the control.

Concerning the cultivars of Ficus alii, the data in Table (4) revealed that, in both seasons, the cv. "Variegata" had significantly higher values of the total chlorophyll contents than the cv. "Green". On the other hand, the carotenoid content in the cv. "Green" was significantly higher than in cv. "Variegata"

Regarding the interaction effect between foliar application of trace elements and Ficus alii cultivars, the data in Table (4) showed that in both seasons within both cultivars of Ficus alii, foliar application of different trace elements resulted in significant increase in total chlorophyll content compared to the untreated control. While, in both seasons, the lowest values recorded on total chlorophyll content of both cultivars were the untreated control plants. The highest values in the first season $(1.09 \mathrm{mg} / \mathrm{g}$ FW) were recorded on the cv. "Green" plants sprayed with Fe treatment, while the highest value in the second season $(1.11 \mathrm{mg} / \mathrm{g}$ fresh weight) was recorded in the cv. "Variegata" sprayed with $\mathrm{Mn}$ or B treatment.

\subsubsection{Total carbohydrates ( $\%$ of dry weight)}

The data recorded on total carbohydrate percentages (Table 4) revealed that foliar spraying of the different trace elements had a beneficial effect on promoting the synthesis and accumulation of carbohydrate percentages in the dried leaves of Ficus alii plants. In both seasons, the values recorded were significantly higher in the plants which received any treatment of the tested trace elements compared to the control. Similar results were reported by El-Deeb (1999) on Aspelinium nidus and Philodendron erubescens, Al-Hadad (2006) on Cupressus macrocarpa, Mazhar et al. (2006) on Taxodium disticum, Abd El-Aziz and Balbaa (2007) on Salvia farinacea, Farahat et al. (2007) on Cupressus sempervirerns, Esmail (2008) on Codiaeum variegatum cv. "Gold Star". Kumar and Haripriya (2010) on Nerium odorum and Eid et al. (2010) on Polianthes tuberose.

Among the different trace elements, in both seasons, the application of $\mathrm{Mn}$ or B treatment appeared to be the most effective for increasing carbohydrate percentage, as it gave higher mean values than those recorded with other treatments and the control plants.

The favorable effect of foliar spraying of the different trace elements on the total carbohydrates percentage may be indirectly attributed to the increase in the content of total chlorophylls. As the synthesis of total chlorophylls was promoted, the rate of photosynthesis increased, leading to an increase in carbohydrate synthesis. 
Table (4): Effect of foliar application of trace elements treatments on the total chlorophylls $(a+$ b), carotenoids content and total carbohydrates treatment in the leaves of Ficus alii cv.s "Green" and "Variegata", during the 2012 and 2013 seasons.

\begin{tabular}{|c|c|c|c|c|c|c|}
\hline \multirow{3}{*}{$\begin{array}{c}\text { *Trace elements } \\
\text { treatments }(\mathbf{T})\end{array}$} & \multicolumn{3}{|c|}{ First season (2012) } & \multicolumn{3}{|c|}{ Second season (2013) } \\
\hline & \multicolumn{2}{|c|}{ Cultivars (C) } & \multirow{2}{*}{$\begin{array}{c}\text { Mean } \\
(\mathbf{T})\end{array}$} & \multicolumn{2}{|c|}{ Cultivars (C) } & \multirow{2}{*}{$\begin{array}{l}\text { Mean } \\
\text { (T) }\end{array}$} \\
\hline & Green & Variegata & & Green & Variegata & \\
\hline \multicolumn{7}{|c|}{ Total chlorophylls $(\mathrm{a}+\mathrm{b})$ content $(\mathrm{mg} / \mathrm{g}$ fresh weight) } \\
\hline Control & 0.47 & 0.44 & 0.46 & 0.43 & 0.62 & 0.73 \\
\hline $\mathbf{Z n}$ & 0.74 & 1.02 & 0.89 & 0.71 & 0.91 & 0.81 \\
\hline $\mathbf{F e}$ & 1.09 & 0.91 & 1.00 & 0.74 & 0.91 & 0.82 \\
\hline Mn & 0.73 & 0.95 & 0.84 & 0.98 & 1.11 & 1.05 \\
\hline $\mathbf{B}$ & 0.78 & 1.07 & 0.92 & 0.85 & 1.11 & 0.98 \\
\hline Mean (C) & 0.76 & 0.88 & --- & 0.74 & 0.93 & $\begin{array}{ll}----- \\
\end{array}$ \\
\hline \multicolumn{7}{|l|}{ L.S.D. (0.05) } \\
\hline $\mathbf{T}$ & \multicolumn{3}{|c|}{0.09} & \multicolumn{3}{|c|}{0.08} \\
\hline $\mathbf{C}$ & \multicolumn{3}{|c|}{0.05} & \multicolumn{3}{|c|}{0.04} \\
\hline T X C & \multicolumn{3}{|c|}{0.13} & \multicolumn{3}{|c|}{0.10} \\
\hline \multicolumn{7}{|c|}{ Carotenoids content (mg/g fresh weight) } \\
\hline Control & 0.61 & 0.35 & 0.48 & 0.92 & 0.45 & 0.69 \\
\hline $\mathbf{Z n}$ & 0.33 & 0.25 & 0.29 & 0.63 & 0.47 & 0.55 \\
\hline $\mathbf{F e}$ & 0.34 & 0.38 & 0.36 & 0.79 & 0.36 & 0.58 \\
\hline Mn & 0.93 & 0.41 & 0.67 & 0.79 & 0.32 & 0.55 \\
\hline B & 1.05 & 0.30 & 0.68 & 0.92 & 0.36 & 0.64 \\
\hline Mean (SL) & 0.65 & 0.34 & ----- & 0.81 & 0.39 & ---- \\
\hline \multicolumn{7}{|l|}{ L.S.D. (0.05) } \\
\hline $\mathbf{T}$ & \multicolumn{3}{|c|}{0.05} & \multicolumn{3}{|c|}{0.04} \\
\hline $\mathbf{C}$ & \multicolumn{3}{|c|}{0.03} & \multicolumn{3}{|c|}{0.02} \\
\hline T X C & \multicolumn{3}{|c|}{0.08} & \multicolumn{3}{|c|}{0.05} \\
\hline \multicolumn{7}{|c|}{ Total carbohydrates (\% of dry weight) } \\
\hline Control & 20.00 & 23.60 & 21.80 & 29.00 & 30.10 & 29.55 \\
\hline $\mathbf{Z n}$ & 30.10 & 31.60 & 30.85 & 32.60 & 31.30 & 31.95 \\
\hline $\mathbf{F e}$ & 29.30 & 30.50 & 29.90 & 26.50 & 36.20 & 31.35 \\
\hline Mn & 33.02 & 33.80 & 33.41 & 32.53 & 33.28 & 32.91 \\
\hline $\mathbf{B}$ & 30.60 & 33.20 & 31.90 & 38.30 & 40.30 & 39.30 \\
\hline Mean (SL) & 28.60 & 30.54 & ---- & 31.79 & 34.24 & ----- \\
\hline \multicolumn{7}{|l|}{ L.S.D. (0.05) } \\
\hline $\mathbf{T}$ & \multicolumn{3}{|c|}{0.92} & \multicolumn{3}{|c|}{1.29} \\
\hline $\mathbf{C}$ & \multicolumn{3}{|c|}{0.65} & & 0.91 & \\
\hline T X C & & 1.30 & & & 1.82 & \\
\hline
\end{tabular}

\footnotetext{
* Zn, Fe and Mn = 50 mg/l $\quad B=10 \mathrm{mg} / \mathrm{l}$
} 
As for the cultivars of Ficus alii, the data recorded that the total carbohydrates percentage (Table 4) showed that, in both seasons the cv. "Variegata" had significantly higher values than those obtained with the cv. "Green".

Regarding the interaction effect between foliar application of trace elements and Ficus alii cultivars, the data in Table (4) showed that, in both seasons, within both cultivars of Ficus alii, the plants receiving a trace element treatments recorded significantly higher values than those recorded with the untreated control. The highest value in the first season (33.80\% of dry weight) was recorded on the cv. "Variegata" sprayed with $\mathrm{Mn}$ treatment, while the highest value in the second year $(40.30 \%$ of dry weight) was recorded on the cv. "Variegata" sprayed with B treatment. On the other hand, in both seasons, the lowest values recorded on carbohydrate percentages of both cultivars were obtained from untreated control plants.

\subsection{3. $N, P$ and $K$ ( $\%$ of dry weight)}

As shown in Table (5) the data indicated that the foliar application of the different trace elements treatments had a considerable effect on the uptake and accumulation of $\mathrm{N}, \mathrm{P}$ and $\mathrm{K} \%$ in the leaves of Ficus alii plants. In both seasons, the plants sprayed with any trace element of the three nutrients were significantly higher than those recorded with the control. Similar increases in the $\mathrm{N}, \mathrm{P}$ and $\mathrm{K} \%$ as a result of the tested treatments have been reported by Said (1997) on Codiaeum variegatum, Al-Hadad (2006) on Cupressus macrocarpa, Mazhar et al. (2006) on Taxodium disticum, Abd El-Aziz and Balbaa (2007) on Salvia farinacea, Rajaie et al. (2009) on Citrus aurantifolia, Esmail (2008) on Codiaeum variegatum cv. "Gold Star". , Kumar and Haripriya (2010) on Nerium odorum, Eid et al.(2010) on Polianthes tuberose and El- Attar (2011) on Areca lutescens.

Among the different trace element treatment, the applications of $\mathrm{Mn}$ followed by Fe treatment were the most effective for increasing the $\mathrm{N} \%$ in the leaves in the first season, whereas the highest mean values in the second season were obtained in plants sprayed with B treatment followed by plants sprayed with $\mathrm{Mn}$ treatment. In both seasons, the most effective treatment for increasing the $\mathrm{P} \%$ in the leaves was spraying the plants with $\mathrm{Fe}$ which gave the highest values (0. 42 and $0.47 \%$ of dry weight in the first and second seasons, respectively followed by spraying the plants with $\mathrm{B}$. It is also clear from the data in Table (5) that in both seasons, foliar application of $\mathrm{Zn}$ treatment was the most effective for increasing the $\mathrm{K} \%$ in the leaves as it gave the highest values $(2.10$ and $2.29 \%$ of dry weight in the first and second seasons, respectively, followed by foliar spraying of B treatment.

As for the cultivars of Ficus alii, the data in Table (5) also showed that in both seasons, the accumulation of $\mathrm{N} \%$ in the leaves of the $\mathrm{cv}$. "Variegata" was significantly higher than the cv. "Green". In the first season, the cv. "Variegata" had $\mathrm{P} \%$ in their leaves significantly higher than in the cv. "Green". However, in the second season, there were no significant differences between the cv. "Green" and the cv. "Variegata" in this respect. The accumulation of $\mathrm{K} \%$ differed from one season to another, where in the first season the cv. "Variegata" had K \% in the leaves which was significantly higher than the cv. "Green". On the other hand, in the second season another trend was obtained, i.e. $\mathrm{K} \%$ in leaves of the cv. "Green" was significantly higher than the cv. "Variegata".

Regarding the interaction effect of foliar application of the different trace elements on N, $\mathrm{P}$ and $\mathrm{K} \%$ in the leaves of Ficus alii cultivars, the data in Table (5) showed that in both seasons, spraying the plants with any trace element caused significant increase in the treatments of the three nutrients in leaves of both cultivars as compared to the control. In both seasons, the highest mean values of $\mathrm{N} \%$ in leaves of both cultivars were obtained from plants sprayed with $\mathrm{Mn}$ treatment followed by plants sprayed with $\mathrm{Fe}$ treatment, whereas the highest mean values of $\mathrm{P} \%$ in leaves of both cultivars were resulted from plants sprayed with Fe treatment followed by plants sprayed with B treatment, while the highest mean values of $\mathrm{K} \%$ in leaves of both cultivars were produced from plants sprayed with $\mathrm{Zn}$ treatment followed by plants sprayed with B treatment( in most cases). On the other hand, in both seasons the lowest values recorded on the three nutrients in leaves of both cultivars were obtained from untreated control plants.

\subsubsection{Zn, Fe, Mn and B (ppm)}

Results of chemical analysis of dried leaves of Ficus alii plants (Table 6) showed that the uptake and accumulation of the different nutrients ( $\mathrm{Zn}, \mathrm{Fe}, \mathrm{Mn}$ and B) were enhanced, and exhibited a similar trend, in response to foliar application of the different treatments. In both 
Table (5): Effect of foliar application of trace element treatments on N, P and K percentage (\% of dry weight) in the leaves of Ficus alii cvs. "Green" and "Variegata", during the 2012 and 2013 seasons.

\begin{tabular}{|c|c|c|c|c|c|c|}
\hline \multirow{3}{*}{$\begin{array}{c}* \text { Trace } \\
\text { elements } \\
\text { treatments }(\mathbf{T})\end{array}$} & \multicolumn{3}{|c|}{ First season (2012) } & \multicolumn{3}{|c|}{ Second season (2013) } \\
\hline & \multicolumn{2}{|c|}{ Cultivars (C) } & \multirow{2}{*}{$\begin{array}{c}\text { Mean } \\
\text { (T) }\end{array}$} & \multicolumn{2}{|c|}{ Cultivars (C) } & \multirow{2}{*}{$\begin{array}{c}\text { Mean } \\
(\mathrm{T})\end{array}$} \\
\hline & Green & Variegata & & Green & Variegata & \\
\hline \multicolumn{7}{|c|}{ N (\% dry weight) } \\
\hline Control & 1.88 & 2.03 & 1.96 & 1.32 & 1.73 & 1.53 \\
\hline $\mathbf{Z n}$ & 2.21 & 2.48 & 2.35 & 2.33 & 2.57 & 2.45 \\
\hline $\mathbf{F e}$ & 2.31 & 2.60 & 2.46 & 2.40 & 2.81 & 2.61 \\
\hline Mn & 2.80 & 2.90 & 2.85 & 2.75 & 3.11 & 2.93 \\
\hline $\mathbf{B}$ & 2.20 & 2.40 & 2.30 & 2.23 & 2.49 & 3.36 \\
\hline Mean $(C)$ & 2.28 & 2.48 & ------- & 2.21 & 2.54 & -ב--- \\
\hline \multicolumn{7}{|l|}{ L.S.D. (0.05) } \\
\hline $\mathbf{T}$ & \multicolumn{3}{|c|}{0.04} & \multicolumn{3}{|c|}{0.05} \\
\hline $\mathbf{C}$ & \multicolumn{3}{|c|}{0.02} & \multicolumn{3}{|c|}{0.03} \\
\hline T X C & \multicolumn{3}{|c|}{0.05} & \multicolumn{3}{|c|}{0.08} \\
\hline \multicolumn{7}{|c|}{ P (\% dry weight) } \\
\hline Control & 0.14 & 0.18 & 0.16 & 0.17 & 0.22 & 0.20 \\
\hline $\mathbf{Z n}$ & 0.28 & 0.29 & 0.29 & 0.31 & 0.31 & 0.31 \\
\hline $\mathbf{F e}$ & 0.39 & 0.44 & 0.42 & 0.46 & 0.48 & 0.47 \\
\hline Mn & 0.23 & 0.26 & 0.25 & 0.29 & 0.32 & 0.31 \\
\hline B & 0.30 & 0.35 & 0.33 & 0.36 & 0.34 & 0.35 \\
\hline Mean (SL) & 0.27 & 0.30 & ------- & 0.32 & 0.33 & ----- \\
\hline \multicolumn{7}{|l|}{ L.S.D. (0.05) } \\
\hline $\mathbf{T}$ & \multicolumn{3}{|c|}{0.04} & \multicolumn{3}{|c|}{0.05} \\
\hline C & \multicolumn{3}{|c|}{0.02} & \multicolumn{3}{|c|}{$\mathbf{0 . 0 3}$} \\
\hline TX C & \multicolumn{3}{|c|}{0.05} & \multicolumn{3}{|c|}{0.08} \\
\hline \multicolumn{7}{|c|}{ K (\% dry weight) } \\
\hline Control & 0.98 & 1.10 & 1.04 & 1.07 & 1.16 & 1.12 \\
\hline $\mathbf{Z n}$ & 2.06 & 2.13 & 2.10 & 2.33 & 2.24 & 2.29 \\
\hline $\mathbf{F e}$ & 2.01 & 1.97 & 1.99 & 2.10 & 2.03 & 2.07 \\
\hline Mn & 1.20 & 1.58 & 1.39 & 2.00 & 1.85 & 1.93 \\
\hline B & 1.98 & 2.04 & 2.01 & 2.31 & 2.16 & 2.24 \\
\hline Mean (SL) & 1.65 & 1.76 & $\begin{array}{ll}--- \\
-\end{array}$ & 1.96 & 1.89 & ----- \\
\hline \multicolumn{7}{|l|}{ L.S.D. (0.05) } \\
\hline $\mathbf{T}$ & \multicolumn{3}{|c|}{0.04} & \multicolumn{3}{|c|}{0.05} \\
\hline $\mathrm{C}$ & \multicolumn{3}{|c|}{0.02} & & 0.03 & \\
\hline T X C & & 0.06 & & & 0.08 & \\
\hline
\end{tabular}

* $\mathrm{Zn}, \mathrm{Fe}$ and $\mathrm{Mn}=50 \mathrm{mg} / \mathrm{l} \quad \mathrm{B}=\mathbf{1 0} \mathrm{mg} / \mathrm{l}$ 
Table (6): Effect of foliar application of trace element treatments on $\mathrm{Zn}, \mathrm{Fe}, \mathrm{Mn}$ and $\mathrm{B}$ contents (ppm) in the leaves of Ficus alii cvs "Green" and "Variegata", during the 2012 and 2013 seasons.

\begin{tabular}{|c|c|c|c|c|c|c|}
\hline \multirow{3}{*}{$\begin{array}{c}* \text { Trace elements } \\
\text { treatments }(\mathbf{T})\end{array}$} & \multicolumn{3}{|c|}{ First season (2012) } & \multicolumn{3}{|c|}{ Second season (2013) } \\
\hline & \multicolumn{2}{|c|}{ Cultivars (C) } & \multirow{2}{*}{$\begin{array}{l}\text { Mean } \\
(\mathrm{T})\end{array}$} & \multicolumn{2}{|c|}{ Cultivars (C) } & \multirow{2}{*}{$\begin{array}{c}\text { Mean } \\
(\mathbf{T})\end{array}$} \\
\hline & Green & Variegata & & Green & Variegata & \\
\hline \multicolumn{7}{|c|}{ Zn (ppm) } \\
\hline Control & 41 & 38 & 39.5 & 33 & 40 & 36.5 \\
\hline $\mathbf{Z n}$ & 85 & 88 & 86.5 & 90 & 96 & 93.0 \\
\hline $\mathbf{F e}$ & 77 & 80 & 78.5 & 88 & 85 & 86.5 \\
\hline Mn & 74 & 80 & 77.0 & 70 & 74 & 72.0 \\
\hline B & 80 & 79 & 79.5 & 75 & 80 & 77.5 \\
\hline Mean (C) & 71.4 & 79 & ------ & 71.2 & 75 & ------ \\
\hline \multicolumn{7}{|l|}{ L.S.D. (0.05) } \\
\hline $\mathbf{T}$ & \multicolumn{3}{|c|}{2.4} & \multicolumn{3}{|c|}{1.7} \\
\hline $\mathbf{C}$ & \multicolumn{3}{|c|}{1.4} & \multicolumn{3}{|c|}{1.0} \\
\hline $\mathbf{T X C}$ & \multicolumn{3}{|c|}{3.4} & \multicolumn{3}{|c|}{2.4} \\
\hline \multicolumn{7}{|c|}{ Fe (ppm) } \\
\hline Control & 174 & 180 & 177.0 & 184 & 193 & 188.5 \\
\hline $\mathbf{Z n}$ & 321 & 340 & 330.5 & 345 & 400 & 372.5 \\
\hline $\mathbf{F e}$ & 399 & 390 & 394.5 & 422 & 420 & 421.0 \\
\hline Mn & 304 & 325 & 314.5 & 410 & 316 & 363.0 \\
\hline B & 301 & 311 & 306.0 & 300 & 469 & 384.5 \\
\hline Mean (SL) & 299.8 & 309.2 & ----- & 332.2 & 359.6 & $\begin{array}{l}---- \\
\end{array}$ \\
\hline \multicolumn{7}{|l|}{ L.S.D. (0.05) } \\
\hline $\mathbf{T}$ & \multicolumn{3}{|c|}{6.1} & \multicolumn{3}{|c|}{5.1} \\
\hline $\mathbf{C}$ & \multicolumn{3}{|c|}{3.5} & \multicolumn{3}{|c|}{3.0} \\
\hline TX C & \multicolumn{3}{|c|}{8.6} & & 7.8 & \\
\hline & & & (ppm) & & & \\
\hline Control & 25 & 29 & 27 & 32 & 38 & 35 \\
\hline Zn & 44 & 46 & 45 & 42 & 50 & 46 \\
\hline Fe & 35 & 38 & 36.5 & 45 & 49 & 47 \\
\hline Mn & 42 & 50 & 46 & 62 & 57 & 59.5 \\
\hline $\mathbf{B}$ & 38 & 43 & 40.5 & 48 & 51 & 49.5 \\
\hline Mean (SL) & 36.8 & 41.2 & ----- & 45.8 & 49 & ----- \\
\hline L.S.D. (0.05) & & & & & & \\
\hline $\mathbf{T}$ & & 2.5 & & & 2.6 & \\
\hline $\mathbf{C}$ & & 1.6 & & & 1.5 & \\
\hline TX C & & 3.6 & & & 3.6 & \\
\hline & & & ppm) & & & \\
\hline Control & 0.37 & 0.42 & 0.40 & 0.44 & 0.47 & 0.46 \\
\hline Zn & 0.56 & 0.62 & 0.59 & 0.68 & 0.72 & 0.70 \\
\hline $\mathbf{F e}$ & 0.64 & 0.73 & 0.69 & 0.90 & 0.83 & 0.87 \\
\hline Mn & 0.55 & 0.65 & 0.60 & 0.70 & 0.75 & 0.73 \\
\hline B & 0.86 & 0.90 & 0.88 & 0.99 & 0.95 & 0.97 \\
\hline Mean (SL) & 0.60 & 0.66 & ------ & 0.74 & 0.74 & ----- \\
\hline L.S.D. (0.05) & & & & & & \\
\hline $\mathbf{T}$ & & 0.05 & & & 0.04 & \\
\hline $\mathbf{C}$ & & 0.03 & & & 0.02 & \\
\hline TX C & & $\mathbf{0 . 0 8}$ & & & 0.05 & \\
\hline
\end{tabular}

\footnotetext{
* Zn, Fe and Mn = 50 mg/l $\quad B=10 \mathrm{mg} / \mathrm{l}$
} 
seasons, the foliar application of different trace elements, regardless of the type of element applied, caused significant increase in these nutrients contents in the leaves of Ficus alii plants, compared to the control. These results are in agreement with the findings of Mattis and Hershey (1992) on Epipremnum aureum and Philodendron scandens, Said (1997) Codiaeum variegatum, Stamps and Rock (2000) Asparagus virgatus, Al-Hadad (2006) Cupressus macrocarpa, Esmail (2008) Codiaeum variegatum cv. "Gold Star", Rajaie et al. (2009) Citrus aurantifolia, Kumar and Haripriya (2010) Nerium odorum, Eid et al. (2010) Polianthes tuberosa and El- Attar (2011) Areca lutescens.

It is also obvious from the data in Table (6) that, in both seasons the highest values of $\mathrm{Zn}, \mathrm{Fe}$ $\mathrm{Mn}$ and $\mathrm{B}$ contents were obtained in the leaves of plants sprayed with treatments of the same elements. In other words, foliar application of each element was the most effective treatment in increasing and accumulating of the same element content in leaves tissues.

The increase in the nutrient content in the leaves tissues of the plant as a result of foliar application of the nutrient solution can be easily explained, since nutrient solution remains on the leaf surface as a thin film which may be accompanied by more absorption from leaf surface, and their accumulation in plant leaves tissues (Taiz and Zeiger, 2002 and Fernandez et al. 2013).

Concerning the cultivars of Ficus alii, the data in Table (6) showed that, in most cases, the uptake and accumulation of $\mathrm{Zn}, \mathrm{Fe} \mathrm{Mn}$ and $\mathrm{B}$ contents in the leaves of the cv. "Variegata" were significantly higher than the cv. "Green". The only one exception to this general trend was recoded in the second season, since there were no significant differences between B content in the leaves of the cv. "Green" and the cv. "Variegata".

Regarding the interaction effect of foliar application of the different trace elements treatments on $\mathrm{Zn}, \mathrm{Fe} \mathrm{Mn}$ and $\mathrm{B}$ contents in the eaves of Ficus alii cultivars, the data recorded in Table (6) indicated that in both seasons, all nutrient contents significantly increased in the leaves of both cultivars as a result of foliar application of trace elements, compared to the untreated control. In both seasons, the highest values of nutrient content in leaves of both cultivars, in most cases, were obtained from plants sprayed with the solution of the same element. On the other hand, lowest values of nutrient content of both cultivars were recorded on the control plants.

Conclusion: Foliar application of the trace elements treatments improved growth and quality of Ficus alii cvs "Green" and "Variegata", the cv. "Variegata" was more responsive than the cv. "Green". The importance of the studied trace elements for both cultivars can be arranged as $\mathrm{Mn}>\mathrm{Fe}>\mathrm{B}>\mathrm{Zn}$.

From the above mentioned results, it can be recommended that for the best vegetative growth of Ficus alii cvs "Green" and "Variegata", foliar spray with $\mathrm{Fe}, \mathrm{Zn}$ or $\mathrm{Mn}$ at $50 \mathrm{mg} / \mathrm{l} / 3$ weeks and/or B at $10 \mathrm{mg} / \mathrm{l} / 3$ weeks and supplied with $2 \mathrm{~g} /$ plant/month of chemical fertilizer (NPK, 2020-20) is recommended.

\section{REFERENCES}

Abd El-Aziz N. G. and Balbaa L. K. (2007). Influence of tyrosine and zinc on growth, flowering and chemical constituents of Salvia farinacea P. Plants J. Appl. Sci. Res., 3(11): 1479-1489.

Al-Hadad Z. Kh. (2006). Effect of some treatments on growth and chemical composition of Cupressus macrocarpa. M.Sc. Thesis, Fac. Agric., Cairo, Univ., Egypt, $83 \mathrm{p}$.

Allen V. B. and David J. P. (2007). Handbook of Plant Nutrition. Taylor and Francis Publishers, NewYork USA. 662p.

Chapman H.D. and Pratt P.F. (1961). Methods of Soil, Plants and Water Analysis. Univ., of California, USA Division of Agricultural Sciences, pp. 60-69.

Dorgham A. H. (2005). Physiological studies on Dieffenbachia, Philodendron and Syngonium plants .M. Sc. Thesis, Fac. Agric., Cairo Univ. Egypt, 193 p.

Dubois M., Smith F., Gilles K. A., Hamilton J. K. and Rebers P. A. (1956). Colorimetric method for determination of sugar and related substances. Anal. Chem., 28 (3): 350-356.

Eid R. A., Khalifa R.Kh. M. and Shaaban S.H.A. (2010). Effect of foliar application of zinc and benzyladenine on growth, yield and chemical constituents of tuberose plants. Res. J Agric. and Biol. Sci., 6 (6): 732743.

El-Attar A. B. (2011). Response of Areca lutescens, Caryota mitis and Chamaedorea elegans palms to nutritional 
and irrigation treatments. Ph.D.. Thesis, Fac. Agric., Cairo, Univ., Egypt, 157 p.

El-Bagoury H. M., Nasr A. A. and El-Tantawy A. A. (2008). Effect of NPK fertlization, trace elements and gibberellic acid on vegetative growth and chlorophyll content of Hedera helix, 1. plants. J. Product. \& Dev., 13(1), 19-27.

El-Deeb E. A. (1999). Effect of Mineral Nutrition, Planting Media and Light on Some Foliage Plants. M.Sc. Thesis, Fac. Agric., Cairo Univ., Egypt, 128 p.

El-Fadaly H. G. (1994). Effect of Chemical Fertilization and Gibberellic Acid $\left(\mathrm{GA}_{3}\right)$ Treatments on Growth, Flowering and Chemical Composition of Jasminum sambac. L. Plants. M.Sc. Thesis, Fac. Agric; Cairo Univ., 172 p.

Esmail S. A. (2008). Physiological studies on croton plant. M.Sc. Thesis, Fac. Agric., Cairo Univ., Egypt, 131 p.

Farahat M. M., Ibrahim S., Taha S. L. and ElOuesni F. M. (2007). Response of vegetative growth and some chemical constituents of Cupressus sempervirens L. to foliar application of ascorbic acid and zinc at Nubaria. World, J. Agric. Sci., 3(3): 282-288.

Fernandez V., Sotiropoulos T. and Brown P. (2013). Foliar Fertilization Scientific Principles and Field Practices. International Fertilizer Industry Association (IFA)., Paris, France.

Gomaa S.A. and Ragab A.A.M (2005). Studies on the effect of microelements and gibberelic acid on Codiaeum variegatum cv. Redii. Egypt. J. Appl. Sci., 20(5):272289.

Heider S. M. A. O. (2010). Effect of chemical fertilization and growing media on vegetative growth and chemical composition on two cultivars of Dracena marginata. M.Sc. Thesis, Fac. Agric., Cairo, Univ., Egypt, 113 p.

Isaac R. A. and Kerber J. D. (1971). Atomic Absorption and Flamephotometry: Techniques and Uses in Soil, Plant, and Water Analysis. In Instrumental Methods for Analysis of Soils and Plant Tissue. Soil Sci. Soc. Amer., Madison, WI, USA, pp 17-37.

Kuepper G. (2003). Foliar fertilization. ATTRA (Appropriate Technology Transfer for Rural Areas), US Dept. Agric., pp: 1-10.
Kumar S. and Haripriya K. (2010). Effect of foliar application of iron and zinc on growth, flowering and yield on nerium (Nerium odorum L.). Plant Archives, 10 (2): 637-640.

Mansour N. M. (2002). A study on the acclimatization of Scindapsus pictus and Hedra helix and their response to chemical fertilization. M.Sc. Thesis, Fac. Agric., Cairo, Univ., Egypt, 131 p.

Marschner H. (1995). Mineral Nutrition of Higher Plants. $2^{\text {nd }}$ ed.,Academic Press, London, UK.

Mattis P. R. and Hershey D. R. (1992). Iron deficiency stress response of Epipremnum aureum and Philodendron scandens. J. Plant Physiol., 139 (4):498-502.

Mazhar A. A. M., Zaghloul S. and Yassen A. A. (2006). Impact of boron fertilizer on growth and chemical constituents of Taxodium distichum grown under water regime. World, J. Agric. Sci., 2(4): 412420.

Naguib N. Y., Hussein M. S., Sherbeny E. S. E., Khalil M. Y. and Lazari D. (2007). Response of Ruta graveolens L. to sowing dates and foliar micronutrients. J. Appl. Sci. Res., 3(11): 1534-1543.

Piper C.S. (1947). Soil and Plant Analysis. Univ. of Adelaide, Adelaide, Australia, pp. 258275.

Pregl P. (1945). Quantitative Organic Microanalysis. Churchill Publishing Co., London, UK., $4^{\text {th }}$ Ed. pp 78-82.

Rajaie M., Ejraieb A. K., Owliaiec H. R. and Tavakolid A. R.(2009). Effect of zinc and boron interaction on growth and mineral composition of lemon seedlings in a calcareous soil. Int., J. Plant Prod. 3(1): 39-50.

Said R. M. (1997). Effect of Some Chemical Fertilization on Croton Plant. M.Sc. Thesis, Fac. Agric., Cairo Univ., Egypt, $180 \mathrm{p}$.

Saric M., Kastrori R., Curic R., Cupina T. and Geric I. (1967). Chlorophyll Determination. Univ. Unoven Sadu Par Ktikum is fiziologize Biljaka, Beogard, Hauncna, Anjiga, P. 215.

Stamps R. and Rock D. K. (2000). Effects of four elements on color, yield and vase life of tree "fern" (Asparagus virgatus). Proceed. Fla. State Hort. Soc., 112:282285. 
Steel R. G. and Torrie S. H. (1980). Principles and Procedures of Statistics. Second Ed., McGraw-Hill Inc., NewYork. USA pp.63. Taiz L. and Zeiger E. (2002). Plant Physiology, $3^{\text {rd }}$ Ed., Sinauer Associates, sunderlan,
MA. 690 pps.

Troug E. and Meyer A. H. (1939). Improvem in deiness colorimetric methods for phosphorus and arsenic. Ind. Eng. Chem. Anal., Ed. 1: 136-139.

استجابه صنفين من الـ Ficus alii L L الى الرش الورقى ببعض معاملات العناصر الصغرى

\author{
أسماء بدرالدين العطار \\ قسم بساتين الزينه - كلية الزراعة - جامعة القاهرة - الجيزة - مصر
}

أجرى هذا البحث داخل الصوبة الزجاجية بمشتل قسم بساتين الزينة بكلية الزر اعة - جامعة القاهرة خلال الموسمين

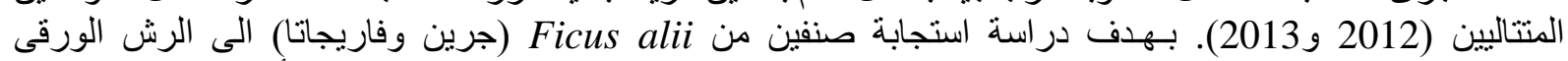

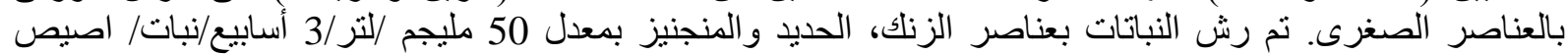

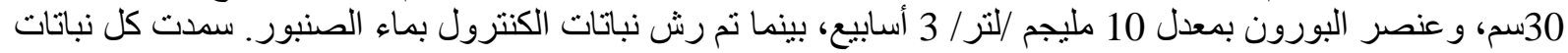

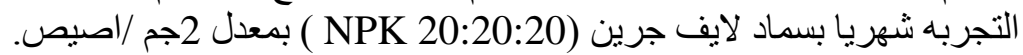

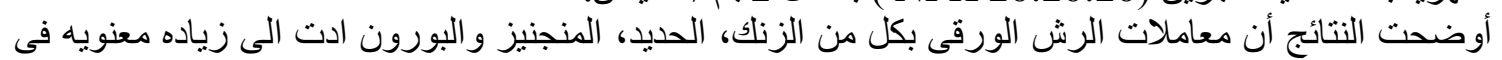

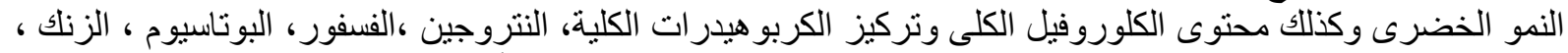

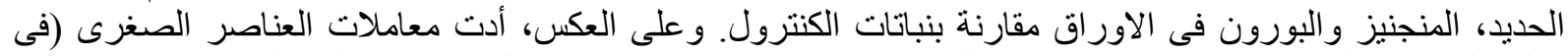

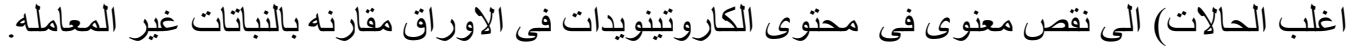

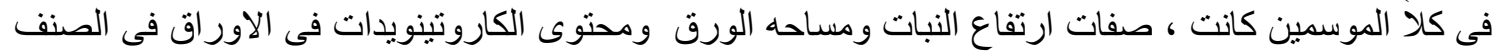

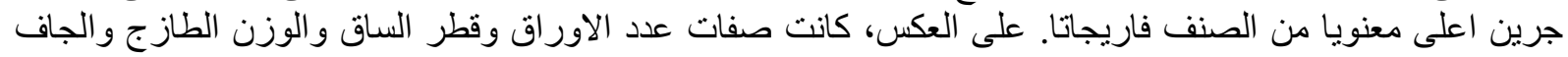

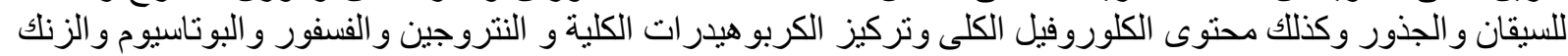

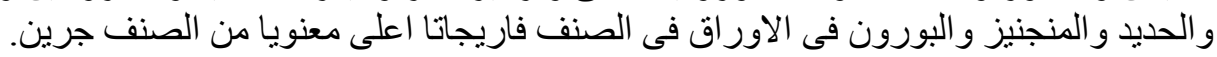

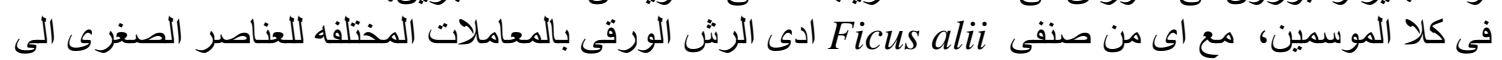

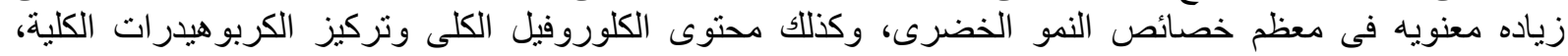

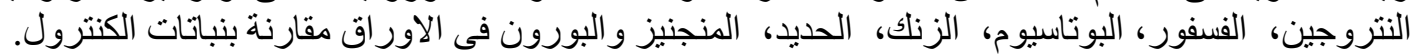

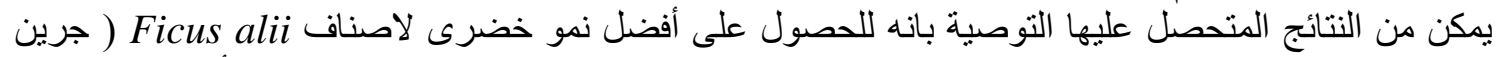

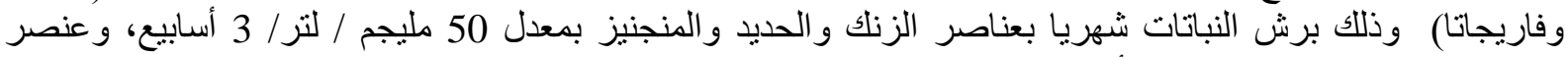
البورون بمعدل 10 مليجم /لتزر / 3 أسابيع . المجلة العلمية لكلية الزراعة - جامعة القاهرة - المجلد (65) العدد الثانى (ابريل 2014):182-170) ـ 